\title{
Comparison of Nutritional Value of Milkfish Shredded with Milkfish Bone Shredded (Chanos Chanos)
}

\author{
Mutemainna Karim ${ }^{1}$, Aryanti Susilowati², Jawiana Saokani², Yeni Savitri Andi Lawi ${ }^{2}$ \\ ${ }^{1}$ Department of Magister Aquatik Resources Management, Maritime Technology and Business Institute, Balik \\ Diwa Makassar, South Sulawesi, Indonesia \\ ${ }^{2}$ Department of Fish Processing Tekonlogy, Maritime Technology and Business Institute, Balik Diwa Makassar, \\ South Sulawesi, Indonesia
}

Article Info

Volume 8, Issue 4

Page Number : 610-618

Publication Issue

July-August-2021

\section{Article History}

Accepted : 10 Aug 2021

Published : 20 Aug 2021

\section{ABSTRACT}

The use of fishbone waste as shredded product is one of the right alternatives to provide a source of calcium-rich food that is cheaper, easier to obtain and of course easily absorbed and reduces the adverse effects of environmental pollution. The purpose of this research is to create a diversified product of milk fishbone shredded as an alternative use of fishery byproducts and to compare the chemical or nutritional characteristics of fishbone shredded and shredded milkfish (Chanos chanos). This study uses a comparative method. The results showed that the nutritional content of fish bone shredded was not much different from shredded milkfish products. The nutritional value of fishbone shredded are: $6.86 \%$ water content, $38.71 \%$ protein content, $17.16 \%$ fat content, $23.63 \%$ carbohydrate content and $1.59 \%$ crude fiber content, $12.04 \%$ ash content, $1.70 \%$ calcium content, and $1.51 \%$ phosphorus content. While the nutritional value of milkfish shredded is: $7.89 \%$ water content, $42.2 \%$ protein content, $31.48 \%$ fat content, $9.30 \%$ carbohydrate content, $1.64 \%$ crude fiber content, $7.49 \%$ ash content, $2.54 \%$ calcium content, and $1.34 \%$ phosphorus content. The nutritional value of fishbone shredded is higher in carbohydrate content, crude fiber content, and ash content compared to milkfish shredded products. The nutrient content of fishbone shredded is lower in water content, protein content, and fat content when compared to milkfish shredded products. High levels of ash in milkfish floss have the potential to be a source of calcium and phosphorus minerals. Thus fishbone shredded can be used as a mineral food source to meet the nutritional needs of the community.

Index Terms - Nutrition, by product, milkfish, fishbones shredded. 


\section{INTRODUCTION}

The Indonesian government designated milkfish as a priority commodity for fisheries industrialization in 2010. The existence of a fishing industry that can process fish into semi-finished products and finished products that are preferred by consumers is becoming increasingly important [1]. According to [2], around $70 \%$ of fish are processed before the final sale. Fish processing involves stunning, leveling, removal of mucus, beheading, washing, scaling, cutting the intestines, cutting fins, separating the bones of meat and steak and fillets. Fish processing is not optimal, there are still many parts of the fish, both the contents of the stomach, head, bones, and tail have not been utilized and will be discarded [3]. A large amount of waste (20-80\%) depending on the level of processing and type of fish) is generated. Generally, the edible portion of fish is around $45-50 \%$ of the body of the fish, the rest is by-product [4]. Whereas according to [5], the total yield of edible milkfish (77.2\%) is the largest portion, the rest is the stomach contents accounted for 9.9\%, bones with meat attached as much as $11.3 \%$, fins are a component that is the smallest is as much as $1.6 \%$ of the total body weight of fish.

By product is a by-product obtained from the production process that is not the main product or often referred to as waste. Along with the development of the fishing industry, the waste generated from the company's production has also increased. Directly or indirectly, this will hurt the environment because it causes pollution [6]. Waste will also be a source of microbial growth that can interfere with the health of the human body [7]. To minimize this impact, efforts should be made to utilize this waste quickly and appropriately. The right way to deal with waste is by applying the concept of zero waste through optimizing the use of waste into raw materials in the development of new products [8].

Advances in science and awareness of the impact of waste on the environment, encourage research on the processing and utilization of waste as a byproduct for food and non-food needs [6]. Fish waste can be used for the production of various value-added products such as protein, oil, amino acids, minerals, enzymes, bioactive peptides, collagen and gelatin [9]. Research on the utilization of solid waste in the fishing industry has been widely developed, such as making chitosan from shrimp shells [10], making gelatin from milkfish bone waste [11], making fish feed using fish waste [12], and others. Waste utilization (by the development of products other than boneless milkfish, such as milkfish shredded, crackers, sticks, and meatballs) have supporting sustainability production of the SME's fish processing unit [13]. Waste management has reduced the impact on the SME's fish processing environment [14].

Solid waste from the fishing industry and household processing is quite large, one of which is fishbone. According to [15], milkfish bone waste produced by the milkfish industry every day reaches $15 \mathrm{~kg}$ or around 5.4 tons per year. Milkfish bones contain $4 \%$ calcium, 3\% phosphorus, and 32\% protein. Milk bones are usually consumed by humans for example when processed into fishery products. Nutrient content in milkfish bones is very beneficial for human bone health because the main elements of milkfish are calcium, phosphorus, protein, and carbonate [16] and [17]. Thus fish bone waste has great potential to be used as raw material for calcium-rich products. The milkfish bones (Chanos chanos) contain nutritional value so that it can prevent osteoporosis. Milkfish bones contain 4\% calcium, 3\% phosphorus, and $32 \%$ protein. [15]. The milkfish bones can be processed into shredded meat so that it will add value to the fishbone waste and boost the community's economy [18] and [19]. Fishbone shredded is a type of preserved food made from fish bones that are added with spices as a flavoring flavor, through the process of steaming, smelting, and frying [20].

Based on the description above, this study aims to create a diversified product of milk fishbone shredded 
as an alternative use of by-products of fisheries that are rich in calcium, as well as to compare chemical or nutritional characteristics of bone shredded meat and milkfish (Chanos chanos). The parameters tested in this study were protein content, fat content, water content, crude fiber, and carbohydrate content, ash content, calcium, and phosphorus content.

\section{METHODOLOGY}

\subsection{Sample Making and Testing}

This research was conducted in July-August 2019. Making samples of shredded meat and shredded milkfish bones (Chanos Chanos) was carried out at UKM 88 Marijo Kab. Pinrang, South Sulawesi Province. The stages of research include the preparation of tools and materials in research. The shredded formula used is seen in Table 1.

TABLE 1. Formulation Of Fishbone Shredded and Fishmeat Shredded

\begin{tabular}{|l|c|c|}
\hline \multicolumn{1}{|c|}{ Material } & $\begin{array}{c}\text { Fishbone } \\
\text { Shredded (A) }\end{array}$ & $\begin{array}{c}\text { Fishmeat } \\
\text { Shredded (B) }\end{array}$ \\
\hline Milkfish Bone & $1000 \mathrm{~g}$ & - \\
\hline Milkfish Meat & - & $1000 \mathrm{~g}$ \\
\hline Coconut milk & $400 \mathrm{ml}$ & $400 \mathrm{ml}$ \\
\hline Garlic & $150 \mathrm{~g}$ & $150 \mathrm{~g}$ \\
\hline Union & $150 \mathrm{~g}$ & $150 \mathrm{~g}$ \\
\hline Salt & $20 \mathrm{~g}$ & $20 \mathrm{~g}$ \\
\hline Brown Sugar & $150 \mathrm{~g}$ & $150 \mathrm{~g}$ \\
\hline Galangal & $50 \mathrm{~g}$ & $50 \mathrm{~g}$ \\
\hline Pepper & $5 \mathrm{~g}$ & $5 \mathrm{~g}$ \\
\hline Cumin & $5 \mathrm{~g}$ & $5 \mathrm{~g}$ \\
\hline Cilantro & $5 \mathrm{~g}$ & $5 \mathrm{~g}$ \\
\hline Lemongrass & $50 \mathrm{~g}$ & $50 \mathrm{~g}$ \\
\hline
\end{tabular}

Sample testing was carried out at the Laboratory of Productivity and Water Quality, Faculty of Marine and Fisheries Sciences, Hasanuddin University, Makassar. The unit of analysis used in this study was shredded bone and shredded milkfish. The parameters tested included water content, protein content, fat content, carbohydrate content, ash content, calcium content, and phosphorus content. The analysis technique to determine nutrient levels in food is the proximate analysis or the Weende method.

\subsection{Data analysis}

This study uses a comparative research method [21]. Data analysis used T-test to determine the comparison of nutrient levels of shredded milkfish and shredded milkfish (Chanos chanos). Furthermore, compared with the 1995 Indonesian National Standard (SNI) that has been set [22].

\section{RESULTS AND DISCUSSION}

The quality of processed milkfish bone waste products can be seen from the nutritional content. The results of the proximate analysis of the nutritional content of shredded bone and shredded milkfish can be seen in Figure 1.

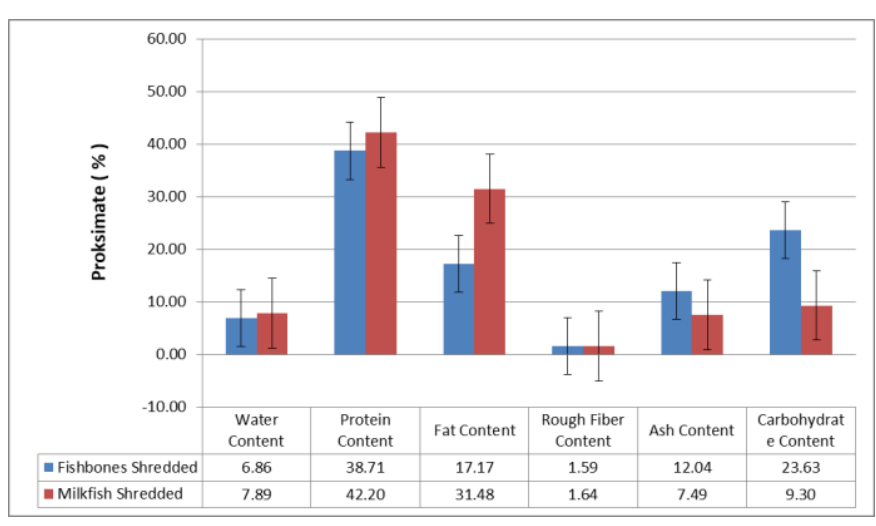

Figure 1. Proximate Test Results of milk fish bone shredded meat and milk fish shredded meat (Chanos chanos).

The biggest chemical component contained in food is water, therefore water is the most important component of food. The water content in food affects the resistance of microbial attack. Water content contained in shredded milkfish products ranges from $6.70 \%$ to $6.99 \%$. The water content of milkfish shredded fish products ranges from $7.8 \%$ to $8.00 \%$. The average water content of milk fishbone shredded products is $6.85 \%$ lower than shredded milkfish meat that is equal to $7.89 \%$ (Table 2). 
TABLE 2. Quality of Fishbone Shredded according to SNI 01-3707-1995.

\begin{tabular}{|c|l|c|c|l|}
\hline No & Nutrition & $\begin{array}{c}\text { Fishbon } \\
\text { Content } \\
\text { Shredde } \\
\text { d } \\
\text { (\% b/b) }\end{array}$ & $\begin{array}{c}\text { Standar } \\
\text { d SNI } \\
1995 \\
(\% \text { b/b) }\end{array}$ & $\begin{array}{c}\text { Kateranga } \\
\text { n }\end{array}$ \\
\hline 1. & Water & 6.86 & Max 7 & Qualify \\
\hline 2. & Protein & 38.71 & Min 15 & Qualify \\
\hline 3. & Fat & 17.17 & Max 30 & Qualify \\
\hline 4. & Fiber & 1.59 & Max 1 & $\begin{array}{l}\text { Not } \\
\text { Qualify }\end{array}$ \\
\hline 5. & Carbohydrat & 23.63 & Max 30 & Qualify \\
\hline 6. & Ash & 12.04 & Max 7 & $\begin{array}{l}\text { Not } \\
\text { Qualify }\end{array}$ \\
\hline 7. & Calcium & 1.70 & - & - \\
\hline 8. & Phosfor & 1.51 & - & - \\
\hline
\end{tabular}

T-Test results show that the water content of milkfish bone shredded products is significantly different from milkfish shredded meat products. The water content of shredded milkfish produced is also higher than [20], which uses different fish bones, namely between $3.16 \%$ to $4.93 \%$. The moisture content of bone shred products produced is following the quality requirements set in SNI 1995 where the maximum moisture content is $7 \%$.

Protein is a food that is very important for the body. The function of protein for the body other than as fuel also functions as a builder and regulator [23]. The protein content of shredded milkfish products ranges from $38.10 \%$ to $39.11 \%$. The protein content of milkfish shredded meat products ranged from $42.00 \%$ to $42.47 \%$. The average value of milk protein shredded protein content of milkfish is $38.71 \%$ lower than the average value of protein content of shredded milkfish which is $42.2 \%$. T-Test results show that the protein content of milkfish bone shredded products is significantly different from the protein content of milkfish milk shredded meat. Even so, the protein content in milkfish shredded and milkfish shredded products is following the quality requirements set in SNI 1995 where the value of protein shredded fish is at least $15 \%$. The level of protein from shredded milkfish produced is far higher than [20], ie $5.66 \%$ to 8.04\%.

Fat is one of the chemical elements found in food and as a source of energy other than protein and carbohydrates. Fat is a mixture of triglycerides in solid form and consists of a solid phase and a liquid phase [24]. Fat in the composition of food ingredients and food raw materials can be useful for adding flavor, but if there are enough of them can trigger rancidity [26]. The level of fat of shredded milkfish products is between $16.34 \%$ to $17.61 \%$. The fat content of shredded milkfish products ranged from $31.20 \%$ to $31.65 \%$. The average fat content of milk fishbone shredded is $17.16 \%$ lower than the fat content of milkfish milk meat that is equal to $31.38 \%$. Fat content in bone shredded products is following the quality requirements that have been set according to SNI 1995 where the maximum fat content is $30 \%$. Based on the results of the analysis of the T-test showed that the value of the fat content of bone shredded products was significantly different from shredded milkfish. The level of fat of shredded milkfish produced is not different from the results of the study [20], namely $15.13 \%$ to $24.54 \%$

Crude fiber is a part of food that cannot be hydrolyzed by chemicals that are used to determine crude fiber content, namely sulfuric acid (H2SO4; $1.25 \%)$ and sodium hydroxide $(\mathrm{NaOH} ; 1.25 \%)$. While dietary fiber is part of food that cannot be hydrolyzed by digestive enzymes. The levels of crude fiber from shredded milkfish products range from $1.45 \%$ to $1.80 \%$. The levels of crude fiber from shredded milkfish products range from $1.33 \%$ to $1.93 \%$. The average level of the crude fiber of shredded milkfish is $1.59 \%$, lower than the level of the crude fiber of shredded milkfish products, which is $1.64 \%$. T-Test results show that the crude fiber content of milk 
fishbone shredded products is not significantly different from milk shredded fish floss. The levels of crude fiber in shredded bone and milkfish products produced are not following the quality requirements that have been set according to SNI 1995 where the maximum crude fiber value is $1.0 \%$.

Carbohydrates are the main source of energy calories for the human body, are useful to prevent the occurrence of excessive body protein breakdown, loss of minerals and are useful to help metabolize fats and proteins. Carbohydrates also have an important role in determining the characteristics of food ingredients such as taste, color, texture, and others [25]. The carbohydrate content of shredded milkfish products ranges from $22.60 \%$ to $24.45 \%$. The carbohydrate content of shredded milkfish products ranges from $8.68 \%$ to $10.06 \%$. The average value of the Cadena carbohydrate of shredded milkfish is $23.63 \%$ higher than the carbohydrate content of milkfish shredded meat that is equal to $9.30 \%$. Based on the results of the T-test showed that the carbohydrate content of milk fishbone shredded products was significantly different from milkfish meat floss. Carbohydrate content in milkfish shredded and milk fishbone shredded products are following SNI 1995 quality requirements where the maximum carbohydrate content is $30 \%$. The level of carbohydrate shredded milkfish produced is far lower than the results of Iskandar, 2016, with a carbohydrate content of $44.92 \%$ to $51.44 \%$.

Ash is an inorganic substance produced from the combustion of organic material. Ash content and composition depends on the type of material. According to [26], ash content is related to minerals of an ingredient. The higher the ash content means the higher the content of inorganic material [23]. Ash and mineral content contained in fishbone shredded and fishmeat shredded can be seen in Figure 2.

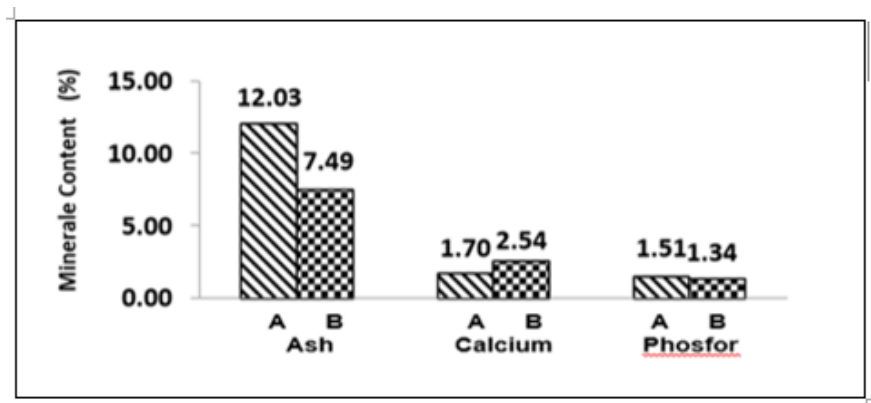

Figure 2. Comparison of Ash, Calcium and

Phosphorus Content of Fishbone Shredded and Fishmeat Shredded.

Ash content of milkfish bone shredded products ranged from $11.68 \%$ to $12.39 \%$. Ash content of milkfish shredded meat products ranged from $7.10 \%$ to $8.01 \%$. The average value of ash content of milkfish bone shredded products is $12.04 \%$ greater than the ash content of milkfish shredded meat products that is equal to $7.49 \%$. Based on the results of the T-test analysis showed that the ash content of bone shredded products was not significantly different from shredded milkfish. According to the provisions of SNI 1995, the maximum ash content for shredded is $7 \%$. Thus the level of milkfish bone shredded and milkfish shredded meat produced exceeds the maximum limit set by SNI 1995. However, the level of milkfish bone shredded meat produced is much lower than [20], which is between $20.47 \%$ to $23.75 \%$. The high ash content is due to the main bone constituent components are minerals. This is in line with the statement [27], ash content obtained from materials related to minerals contained in it. According to [28], living bones and intracellular matrix are contained in the form of mineral salts. Mineral salt is a component consisting of $80 \%$ calcium phosphate and the rest consists of calcium carbonate and magnesium phosphate.

The calcium content of milk fishbone shredded ranges from $1.46 \%$ to $1.84 \%$ while the calcium content of milkfish meat shredded products ranges from $2.49 \%$ to $2.58 \%$. The average value of calcium milk shredded bone of milkfish is $1.70 \%$ lower than 
the calcium content of milk shredded milkfish product that is equal to $2.54 \%$. T-Test results show that the calcium content of bone shredded products is significantly different from milk shredded milkfish. Shredded calcium levels are not listed in SNI-013707-1995. Adequate calcium recommended for adults is $500-800 \mathrm{mg}$ per day [29]. Calcium is useful to help the process of formation of bones and teeth and is needed in blood clotting, muscle contraction, signal transmission in nerve cells. Calcium can help prevent osteoporosis. Most of the calcium is concentrated in cartilage and teeth, the rest is in body fluids and soft tissues [30].

Phosphorus levels of milkfish bone shredded products range from $1.35 \%$ to $1.76 \%$, while the phosphorus content of shredded milkfish products ranges from $1.33 \%$ to $1.35 \%$. The levels of phosphorus contained in milkfish shredded products are on average $1.51 \%$, higher than the phosphorus content contained in milkfish shredded products with an average value of $1.34 \%$. Based on the results of the T-test showed that the level of phosphorus of shredded milkfish products was not significantly different from shredded milkfish. Abon phosphorus levels are not listed in SNI-013707-1995. Phosphorus is one of the minerals needed with an amount of approximately $22 \%$ of all minerals found in the body. Phosphorus is a macromineral that has an important role in the body, not only plays a role in various biological processes but also includes energy metabolism and bone mineralization [31]. Phosphorus is the second most mineral in the human body after calcium, which is $1 \%$ of body weight. Approximately $80 \%$ of phosphorus in the body is stored as calcium phosphate salts, which are part of hydroxyapatite crystals in bones and teeth [32].

\section{CONCLUSION}

Based on the results of the study it can be concluded that the milkfish shredded product has a quality that is not much different from the shredded milkfish product. The nutritional value of milkfish shredded milkfish is: $6.86 \%$ water content, $38.71 \%$ protein content, $17.16 \%$ fat content, $23.63 \%$ carbohydrate content and $1.59 \%$ crude fiber content, $12.04 \%$ ash content while the meat abon nutrition value is: water content $7.89 \%$, $42.2 \%$ protein content, $31.48 \%$ fat content, $9.30 \%$ carbohydrate content, $1.64 \%$ crude fiber content, $7.49 \%$ ash content. The nutritional value of milkfish bone abon is higher in carbohydrate content, crude fiber content, and ash content compared to milkfish shredded meat products. The nutrient content of milk fishbone shredded is lower in water content, protein content, and fat content when compared to milkfish shredded meat products. High levels of ash in milkfish floss have the potential to be a source of calcium and phosphorus minerals. Shredded milkfish can be used as a mineral food source to meet the nutritional needs of the community.

\section{REFERENCES}

[1]. Rahmantya, K.F., A.D. Asianto, D. Wibowo, T. Wahyuni, dan W.A. Somad. 2015. Analisis Data Pokok Kementerian Kelautan dan Perikanan. Pusat Data Statistik dan Informasi. KKP. 2015.

[2]. Nemati, M., N. Huda, dan F. Ariffin. 2017. Development of Calcium Supplement from Fish Bone Wastes of Yellowfin Tuna (Thunnus albacares) and Characterization of Nutritional Quality. International Food Research Journal 24(6): 2419-2426.

[3]. Fitri, A., R.B.K. Anandito, dan Siswanti. 2016. Penggunaan Daging dan Tulang Ikan Bandeng (Chanos chanos) Pada Stik Ikan Sebagai Makanan Ringan Berkalsium dan Berprotein Tinggi, Jurnal Teknologi Hasil Pertanian, Vol. IX, No. 2

[4]. Ikasari, D. Syamdidi, dan D.S. Theresia. 2011. Penggunaan Bakteri Asam Laktat dan Lemak Sapi dalam Pengolahan Limbah Tuna Menjadi Sosis Ffermentasi. Jurnal Pascapanen dan 
Bioteknologi Kelautan dan Perikanan, 6(2):101110.

[5]. Panggat, E. B., 2003. Product Innovations From Tuna And Milkfish Processing By-Products For Human Food Consumption. College of Fisheries and Ocean Sciences University of the Philippines in the Visayas Miagao, Iloilo, Philippines 5023

[6]. Arvanitoyanis, I.S., dan A. Kassaveti. 2008. Fish Industry Waste: Treatments, Environments Impacts, Current and Potential Uses. International Journal on Food Sicience and Technology 43: 726-745.

[7]. Firlianty. 2009. Pemanfaatan Limbah Udang (Penaeus sp.) Sebagai Alternatif Bahan Pengolahan Kerupuk untuk Mengurangi Resiko Pencemaran Lingkungan. Jurnal Perikanan Tropis 4(2): 450-459.

[8]. Haryati S, Munandar A. 2012. Penerapan Konsep Zero Waste pada Pengolahan Abon Ikan Bandeng (Chanos chanos). Jurnal Perikanan dan Kelautan, 2(2): 127-130.

[9]. Ghaly A.E., V.V. Ramakrishnan, M.S. Brooks, S.M. Budge, dan D. Dave. 2013. Fish Processing Wastes as a Potential Source of Proteins, Amino Acids and Oils: A Critical Review. J Microb Biochem Technol 5: 107-129. doi:10.4172/1948-5948.1000110

[10]. Mirari, Y., Arancibia, A. Alemen., M.M. Calvo, M.E. Lopez-Caballro, P. Montero, and M.C. Gomez-Gullen. 2014. Antimicrobial and Antioxidant Chotosan Sollution Enriched with Active Shrimp (Litopenaeus vennamei) Waste materials. Food Hydrocolloids. 35:710-717.

[11]. Marzuki, A., E. Pakki, F. Zulfikar. 2011. Ekstraksi dan Penggunaan Gelatin dari Limbah Tulang Ikan Bandeng (Chanos chanos) sebagai Emulgator dalam Formulasi Sediaan Emulsi. Majallah Farmasi dan Farmakologi 15(2): 63-68.

[12]. Yano, Y., H. Oikawa, M. Satomi. 2008. Reduction of Lipids n Fish Meal Prepared from Fish Waste by a Yeast Yarrowia Lipolytica.
International Journal of Food Microbilogy 121(3): 302-307.

[13]. Salman, D., M. Karim, G. Jalil, and Rahmadanih. 2020. Relationship Between Institutional Sustainability and SMEs Production Sustainability(Case Study: SMEs of Fish Processing Unit, in Pinrang Regency, Indonesia). IOP Conf. Series: Earth and Environmental Science 473 doi:10.1088/17551315/473/1/012045.

[14]. Karim, M., D. Salman, G. Jalil, and Rahmadanih. 2020. Competitiveness and SMEs Production Sustainability Through The Cleaner Production (case study: SMEs of fish processing unit in Pinrang Regency, Indonesia). IOP Conf. Series: Earth and Environmental Science 473 doi:10.1088/1755-1315/473/1/ 012019.

[15]. Adawiyah 2014 , Serburia Suplemen Tulang Ikan Bandeng dengan Cangkang Kapsul Alginat Untuk Mencegah Osteoporosis, Jurnal Ilmiah Mahasiswa, Vol. 4 No.1.

[16]. Lestari, 2001. Pemanfaatan Tulang Ikan Tuna (limbah) untuk Pembuatan Tepung Tulang. Skripsi. Fakultas Perikanan dan Ilmu Kelautan. IPB. Bogor

[17]. Salitus, S., D. Ilminingtyas, dan E. Fatarina. 2017. Penambahan Tepung Tulang Bandeng (Chanos chanos) dalam Pembuatan Kerupuk Sebagai Hasil Samping Industri Bandeng Cabut Tulang. The Addition of Bone Milkfish (Chanos chanos L.) Flour in Making Crackers as Side Product of Boneless Milkfish Industry. EJournal Serat Acitya Volume 6 Nomor 2017.

[18]. Karim, M., D. Salman, J. Genisa, Rahmadanih. 2019. Income Analyisi, Added Value, and Sustainability Strategy of Fish Processing Units (Case: "SMEs 88 Marijo, in Pinrang Regency, South Sulawesi). IJSRST 6(6):221-231. Doi: https://doi.org/10.32628/ IJSRST196641

[19]. Djauhari, A.B. dan F. Kurnia. 2017. Usaha Produktif Abon Kalsium Berbahan Dasar Duri Ikan. Jurnal Pengabdian LPPM Fakultas 
Pertanian Universitas Dr. Soetomo Surabaya, Vol. 02. E-ISSN : 2407-7100.

[20]. Iskandar, J., Herpandi., Nopianti, R. 2016. Pemanfaatan By - Product dari Hasil Produksi Filet Ikan dalam Pembuatan Abon. Sumatera Selatan: Program Studi Teknologi Hasil Sudoyo. 2009. Buku Ajar Ilmu Penyakit Dalam. Jilid II, Edisi V. Interna Publishing. Jakarta.

[21]. Nazir, Moh. 2005. Metode Penelitian. Jakarta: Ghalia Indonesia.

[22]. Badan Standarisasi Nasional.1995. SNI 01-37071995. Tentang Abon. Jakarta.

[23]. Winarno,F.G. 1997. Kimia Pangan dan Gizi.PT Gramedia Pustaka Utama, Jakarta.

[24]. Buckle. K.A., R.A. Edward, G.H. Fleet and M. Wooton. 2007. Ilmu Pangan. Penerjemahan Hari Purnomo dan Adiono. Universitas Indonesia Press, Jakarta.

[25]. Winarno, F.G., 1994. Bahan Tambahan Makanan. Gramedia Pustaka Utama. Jakarta.

[26]. Sudarmadji, S.B., Haryono dan Suhardi. 2003. Prosedur Analisa untuk Bahan Makanan dan Pertanian. Liberty. Yogyakarta.

[27]. Widrial, R. 2005. Pengaruh Penambahan Konsentrasi Tepung Meizena terhadap Mutu Nugget Ikan Patin (Pangisius hypophotalmus. Skripsi. Fakultas Perikanan dan Ilmu Kelautan Universitas Bung Hatta. Padang.

[28]. Frandson, R. D. 1992. Anatomi dan Fisiologi Ternak. Gadjah Mada University Press. Yogyakarta.

[29]. Widyakarya Nasional Pangan dan Gizi. 2010. Penurunan Stunting Melalui Revitalisasi Ketahanan Pangan dan Gizi dalam Rangka Mencapai Pembangunan Berkelanjutan. Jakarta.

[30]. Almatsier, S. 2002. Prinsip Dasar Ilmu Gizi. Jakarta: PT. Gramedia Pustaka Utama. Jakarta.

[31]. Riana, R., G. Garg, S.K. Sheti, M.J. Schreiber, J.F. Simon, and G. Thomas. 2012. Phosphorus Metabolism Review]. J. Nephrol Ter. S3:008. doi:10.4172/2161-0959.S3-008.
[32]. Uribarri, J. 2007. Phosphorus Homeostatis in Normal Health and Chronic Kidney Disese Patient with Special Emphasis on Dietary Phosphorus Intake. Seminars in Dialysis. 20(4);295-301 doi:10.1111/J.1525139X.2007.00 309.x

\section{Cite this article as :}

Mutemainna Karim, Aryanti Susilowati, Jawiana Saokani, Yeni Savitri Andi Lawi, "Comparison of Nutritional Value of Milkfish Shredded with Milkfish Bone Shredded (Chanos Chanos) ", International Journal of Scientific Research in Science and Technology (IJSRST), Online ISSN : 2395-602X, Print ISSN : 2395-6011, Volume 8 Issue 4, pp. 611-618, July-August 2021. Available at doi : https://doi.org/10.32628/IJSRST2183129 Journal URL : https://ijsrst.com/IJSRST2183129 